\title{
DESAIN TUNGKU BRIKET BIOMASSA SYSTEM KONTINYU SEBAGAI TEKNOLOGI PEMANFAATAN ENERGI ALTERNATIF PENGGANTI BAHAN BAKAR TERPAKAI PADA OVEN TEMBAKAU DI MASYARAKAT PEDESAAN
}

\author{
MADE WIJANA ${ }^{1}$ DAN NURCHAYATI ${ }^{2}$ \\ 1,2 Jurusan Teknik Mesin,Universitas Mataram \\ JI Majapahit no.62 Mataram Lombok NTB \\ Email.Wijanamd23@yahoo.co.id
}

\begin{abstract}
Abstrak
Semakin menipisnya cadangan minyak dunia yang menyebabkan harga bahan bakar minyak (BBM) terus melambung. Tungku spiral berbahan bakar minyak tanah, merupakan komponen utama pada oven (omprongan) tembakau yang ada di NTB, yang mana potensi tembakau Virginia sebanyak 45.534 ton dan memerlukan minyak tanah 45 juta liter. Tembakau yang banyak tersebut terancam tidak dapat dikeringkan akibat mahal dan langkanya minyak tanah sebagai bahan bakar utama. Sementara energy alternative pengganti berupa bongkahan batu bara dan kayu bakar tidak memberikan solusi yang baik. Untuk itu dalam penelitian ini didesain tungku yang kemudahan pengoperasiannya menyerupai kombinasi tungku minyak tanah dan tungku bongkahan batu bara dengan memanfaatkan kelebihan dan memperbaiki kelemahan-kelemahannya. Dengan tungku yang mudah dioperasikan sebagai alat pemanfaat energi alternative dan terbarukan, maka masyarakat akan tertarik untuk menggunakannya, ini akan berdampak pada menurunnya biaya pengovenan tembakau.

Metode yang digunakan dalam penelitian ini adalah eksperimen langsung, untuk mengetahui kinerja tungku spiral dilakukan beberapa pengujian. Untuk mendapatkan kesepadanan kemampuan pemanasan antara tungku spiral berbahan bakar minyak tanah dengan tungku desain baru berbahan bakar briket, dilakukan pengujian nilai kalor dan perhitungan jumlah alur briket yang diperlukan, selanjutnya dilakukan pengujian boilling time pada masing-masing tungku. Dan untuk mengetahui peningkatan waktu operasional tungku baru dibanding bahan bakar alternatif lain, dapat dilakukan pengujian lama nyala dalam satu kali pengisian tungku briket. Serangkain pengujian ini dilakukan untuk mengetahui apakah tungku desain baru ini layak digunakan pada omprongan tembakau.

Dari hasil pengujian nilai kalor diperoleh bahwa nilai kalor tertinggi adalah minyak tanah dengan nilai kalor, 9.828,2816 Kkal/kl, dan yang terendah adalah briket biomassa dengan nilai kalor 4.996,5028 Kkal/kg. Pada tungku spiral diperoleh kecedrungan bahwa semakin besar stelan, maka $n$ boilling time semakin kecil (cepat) dan kebutuhan bahan bakar yang semakin besar. Waktu yang dibutuhkan untuk mendidihkan 1 liter air (boiling time) yang paling kecil (cepat) adalah pada stelan ke 4 yaitu 178,67 detik, pada posisi ini, kebutuhan bahan bakarnya terbesar yaitu 103,33 ml. dari pengujian tungku briket desain baru yang menggunakan dua bahan bakar alternative, boilling time kedua bahan bakar alternative (briket) tersebut masih lebih besar dibandingkan dengan tungku spiral stelan ke 4. yaitu masing-masing 390.67 detik untuk briket biomassa dan 255.33 detik untuk briket batubara. Sedangkan dilihat dari boiling time tungku spiral stelan ke 2 yang memiliki nilai 437.33, maka kedua bahan bakar alternative yang menggunakan tungku desain baru, memiliki boiling time yang lebih kecil (cepat) dan dari pengujian lama operasional tungku berbahan bakar briket biomassa, dibandingkan dengan bongkahan batubara dan kayu bakar, diperoleh peningkatan lama operasional sebanyak tiga kali lipat. Bongkahan batubara dan kayu bakar, dalam satu kali pengisian dapat beroperasi selama maksimal 2 jam, sedangkan tungku desain baru berbahan bakar biomassa, dapat beroperasi 6 jam dalam satu kali pengisian. Sedangkan Mekanisme kerja penekan briket, alur briket dan penahan ruang pembakaran dapat berjalan sesuai fungsinya sehingga, kontinyuitas tungku dalam 1 kali pengisian dapat berjalan dan beroperasi dengan stabil selama 6 jam. Dari kinerja tersebut, maka tungku desain baru layak menggantikan tungku spiral pada omprongan tembakau.
\end{abstract}

Kata kunci: Omprongan tembakau, tungku briket, kesepadanan. 


\section{Latar Belakang}

Semakin menipisnya cadangan minyak dunia yang menyebabkan harga bahan bakar minyak (BBM) terus melambung. Seperti halnya oven (omprongan) tembakau yang ada di NTB, terancam tidak dapat dikeringkan akibat mahal dan langkanya minyak tanah sebagai bahan bakar utama.

Dari potensi tanam tembakau virginia di wilayah NTB, khususnya Pulau Lombok, mencapai 58.516 hektare (ha). Pada musim tanam tahun 2008, areal tanam tembakau virginia yang digarap mencapai 22.019 ha untuk dapat memproduksi sebanyak 45.534 ton atau sekitar $90 \%$ kebutuhan tembakau virginia nasional. Kebutuhan minyak tanah bersubsidi untuk omprongan tembakau virginia di wilayah NTB menggunakan 13.509 unit oven mencapai 45 juta liter disisi lain, pemerintah yang terus mengurangi kuota minyak tanah setiap tahun. Pemerintah dan masyarakat NTB telah berusaha mencari solusinya dengan menggunakan bahan bakar alternatif berupa bongkahan batubara dan kayu bakar. Pada bahan bakar bongkahan batubara, disamping panas yang dihasilkan tidak stabil karena masih dalam bentuk bongkahan, dan juga dalam satu kali periode pengovenan harus dilakukan beberapa kali pengisian bahan bakar ke dalam tungku Untuk Bahan bakar kayu bakar, selama ini banyak digunakan karena harganya murah, mudah didapat dan pengoperasiannya mudah, tetapi menimbulkan masalah serius terutama pada kerusakan hutan yang bisa mencapai seluas 12.000 hektare per tahun dan akibat negatif turunannya. Kondisi ini menyebabkan masalah serius yang perlu dicari solusinya Diantaranya dengan menggali potensi energi baru dan terbarukan seperti : energi biomassa, energi angin, matahari dan gelombang laut dan lainnya.
Walaupun telah banyak dibuat alat-alat untuk memanfaatkan energi alternatif seperti pembuatan tungku batubara dan kayu bakar dan briket arang yang selama ini ada, tetapi tungku-tungku briket yang ada selama ini belum banyak digunakan sebagai pengganti minyak tanah oleh masyarakat pengoven tembakau,. Yang menjadi kendala utama tidak digunakannya tungku briket tersebut adalah karena kurang praktisnya penggunaan tungku (Suryadi, 1994). Ketidak praktisan operasional tungku briket biomassa ini, khususnya terletak pada pengisian briketnya tidak bisa kontinyu, dalam satu kali pengisian hanya bisa digunakan untuk \pm 2 jam pengovenan sehingga dalam satu hari pengovenan yang membutuhkan waktu \pm 24 jam, memerlukan pengisian sebanyak 12 kali, sehingga disamping panas yang dihasilkan kurang stabil, diperlukannya tenaga ekstra untuk kegiatan pengisian bahan bakar tersebut. Disamping belum adanya penelitian tentang komposisi dan dimensi briket biomassa yang sesuai untuk oven tembakau. Berdasar masalah tersebut maka dalam penelitian ini perlu diteliti bagaimana mendapatkan desain tungku yang mudah dalam pengoperasiannya dan bagaimana komposisi dan dimensi bahan bakar briket biomasa yang sesuai dengan oven tembakau.sehingga masyarakat tertarik untuk mengaplikasikan tungku briket biomassa ini.

\section{Metode Penelitian}

Penelitian adalah suatu rangkaian proses yang saling terkait secara sistematis. Langkah-langkah penelitian dapat digambarkan seperti berikut : 


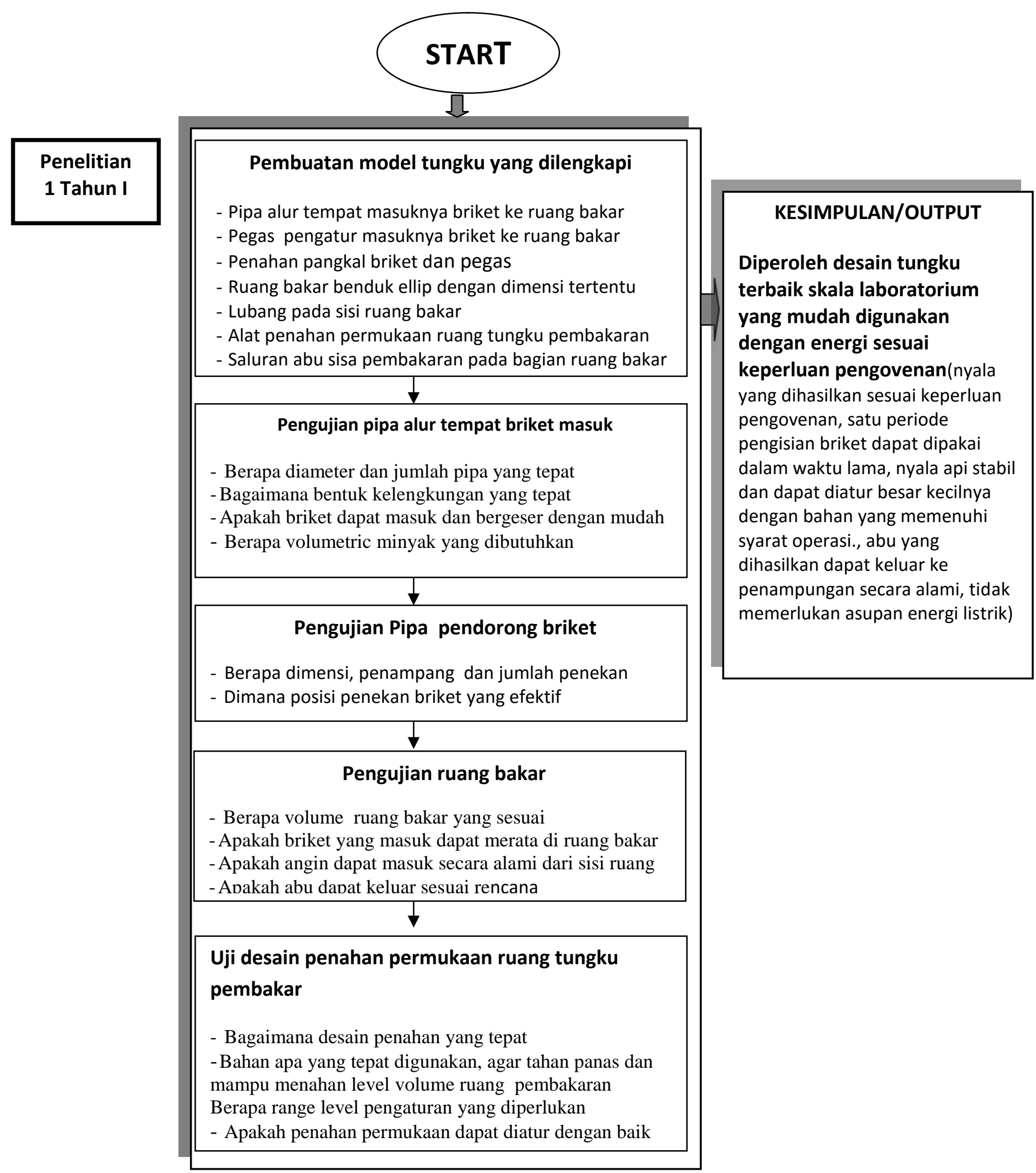

Gambar 1. Langkah-langkah penelitian

3. Hasil Dan Pembahasan

a. Pengujian nilai kalor bahan bakar

Pengujian nilai kalor untuk tiga variasi

bahan bakar yaitu minyak tanah, briket biomassa dan briket batubara, dapat diperoleh data seperti pada gambar 2 berikut. 


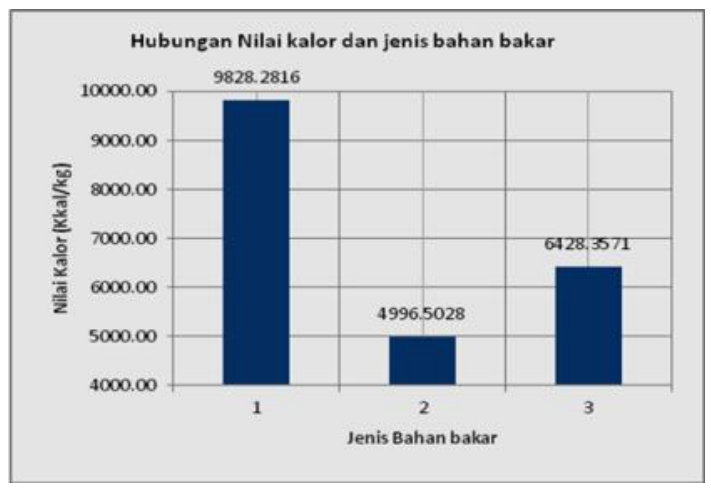

Gambar 2. Grafik hubungan nilai kalor dengan jenis bahan bakar

Dari Gambar 2 menunjukkan bahwa dari ketiga bahan bakar yang diuji, nilai kalor tertinggi adalah minyak tanah dengan nilai kalor, 9.828,2816 Kkal/kl, dan yang terendah adalah briket biomassa yang merupakan campuran $20 \%$ biji jarak kepyar dan $80 \%$ arang sekam padi, dengan nilai kalor 4.996,5028 Kkal/kg.

b. Pengujian Boiling Time Pada Tungku Spiral Omprongan Tembakau Sesuai Stelan

Boiling time adalah waktu yang dibutuhkan untuk memanaskan air pada panci/ketel, yaitu dihitung mulai dari mulai pemanasan air pada suhu kamar, dari tungku yang sudah menyala stabil sampai air mendidih pada suhu sekitar $100^{\circ} \mathrm{C}$. Penggunaan tungku spiral pada omprongan tembakau menggunakan empat stelan sesuai dengan peruntukannya. Dan masingmasing stelan memiliki boilling time dan kebutuhan minyak tanah yang berbedabeda. Dan hasil penelitian diperoleh data boiling time dan kebutuhan minyak tanah pada masing-masing stelan seperti pada gambar 3 .

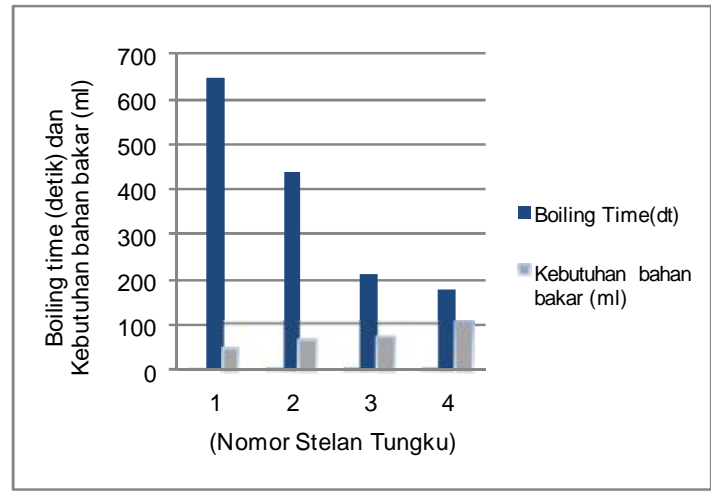

Gambar 3 Grafik hubungan antara variasi stelan tungku terhadap Boiling Time dan kebutuhan bahan bakar dengan stelan tungku
Berdasarkan gambar 3 yang diperoleh, maka dapat diketahui bahwa, semakin besar stelan (bukaan katup bahan bakar), menyebabkan boilling time semakin kecil (cepat) dan kebutuhan bahan bakar yang semakin besar. Waktu yang dibutuhkan untuk mendidihkan 1 liter air ( boiling time) yang paling kesil (cepat) adalah pada stelan ke 4 yaitu 178,67 detik, pada posisi ini, kebutuhan bahan bakarnya terbesar yaitu $103,33 \mathrm{ml}$. Sedangkan boiling time yang paling besar (lama) adalah pada stelan 1 yaitu 645,33 detik, dan memerlukan bahan bakar yang paling sedikit yaitu $46,67 \mathrm{ml}$.

\section{c. Sensibel Heat (SH)}

Sensibel Heat (SH) adalah jumlah energi kalor yang dibutuhkan untuk menaikkan suhu air yaitu diukur pada saat sebelum dan sesudah air mendidih. Dari hasil penelitian, diperoleh grafik hubungan anatara variasi stelan tungku dengan Sensibel Heat (SH) atau jumlah energi kalor yang dibutuhkan untuk menaikkan suhu air pada saat sebelum dan sesudah air mendidih sebagai berikut:

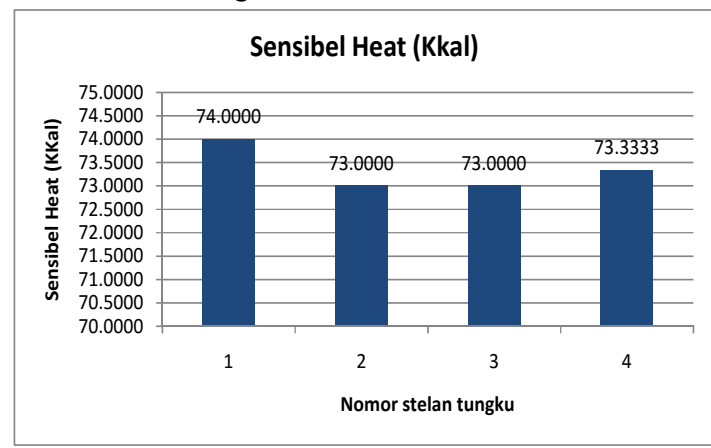

Gambar 4 Grafik hubungan stelan tungku dengan Sensibel Heat

Dari Gambar 4 dapat diketahui bahwa sensible heat (kalor yang dibutuhkan untuk mamanaskan 1 liter air) tidak berbeda secara signifikan antar variasi stelan tungku. Jadi dengan stelan tungku yang berbeda, maka kebutuhan kalor yang dibutuhkan air dari suhu kamar menjadi mendidih adalah sama.

\section{d. Energi Kalor Masukan}

Energi Kalor masukan adalah jumlah energi kalor yang tersedia dalam bahan bakar. Berdasarkan hasil penelitian diperoleh grafik hubungan anatara variasi stelan tungku dengan Energi kalor masukan sebagai berikut: 


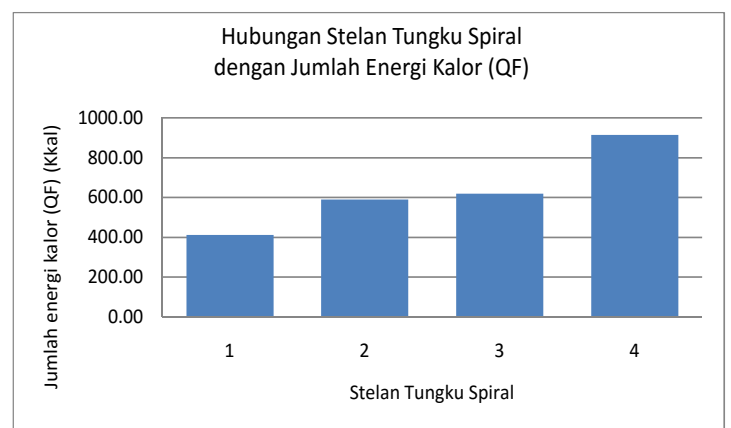

Gambar 5. Grafik hubungan stelan tungku spiral dengan besar energi kalor masukan

Dari Gambar 5 menunjukkan bahwa ada pengaruh yang signifikan antara stelan tungku spiral terhadap energy kalor masukan yang dihasilkan. Semakin besar stelan tungku (bukaan katup) yang digunakan, maka semakin besar energi kalor masukan (untuk memanaskan 1 It air dibutuhkan energi yang lebih banyak). Energi kalor masukan paling besar diperoleh pada stelan 4 dengan nilai $914.03 \mathrm{kkal}$, sedangkan nilai paling kecil terjadi pada stelan 1 dengan nilai 412.79 kkal. Hal ini menunjukkan bahwa semakin besar stelan tungku (bukaan katup bahan bakar), energy yang diberikan untuk memanaskan 1 It air semakin besar, hal ini yang menyebabkan waktu yang dibutuhkan untuk memanaskan air semakin kecil (cepat).

\section{e. Perhitungan Kebutuhan Briket yang sepadan dengan minyak tanah}

(1) Perhitungan jumlah alur briket untuk kesepadanan tungku spiral dan tungku briket

Dalam perhitungan jumlah alur briket pada tungku rancangan dibandingkan dengan tungku spiral berbahan bakar minyak tanah, untuk mengoptimalkan kesepadanan fungsi, maka diambil perbandingan antara tungku spiral berbahan bakar minyak tanah dengan tungku baru yang berbahan bakar briket biomassa. dengan tungku baru yang berbahan bakar briket biomassa.

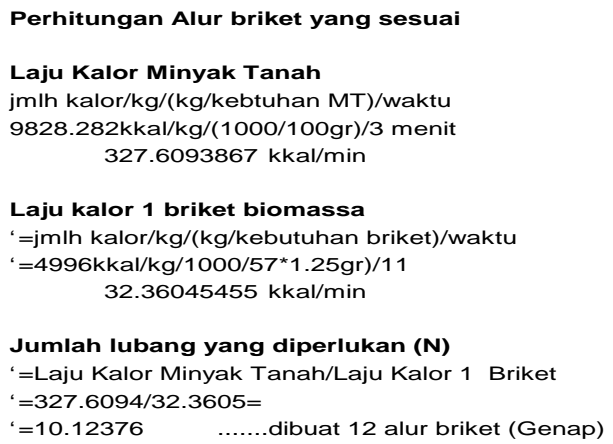

(2) Perhitungan Boilling time ke tiga bahan bakar yang diuji.

Boilling time adalah waktu yang dibutuhkan untuk memanaskan air pada panci/ketel, yaitu dihitung mulai dari mulai pemanasan air pada suhu kamar, dari kompor tungku yang sudah menyala stabil sampai air mendidih pada suhu sekitar $100^{\circ} \mathrm{C}$. Pada pengujian ini, dilakukan penggujian penggunaan tungku spiral pada omprongan tembakau yang menggunakan empat stelan sesuai dengan peruntukannya. Untuk tungku spiran menggunakan stelan maksimum (4) dan tungku yang baru, menggunakan stelan maksimum yaitu saat penggunakan 12 lubang briket. Dan hasil penelitian diperoleh data boilling time untuk masing-masing bahan bakar seperti pada gambar 6 berikut:

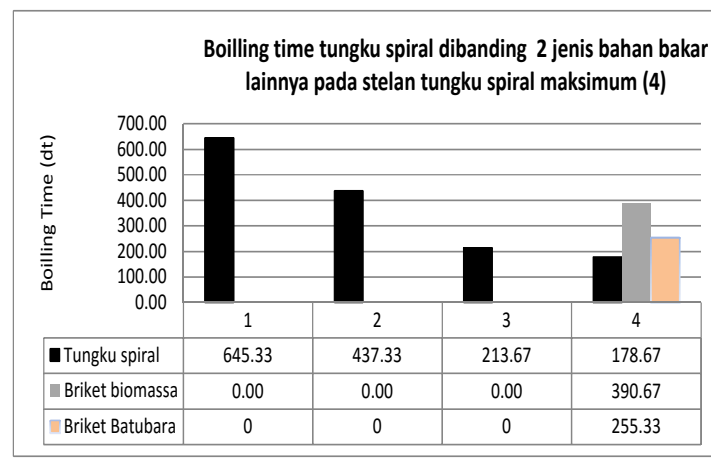

Gambar 6 Grafik boilling time ketiga jenis bahan bakar pada stelan maksimum

Berdasarkan gambar 6. yang diperoleh, maka untuk tungku spiral berbahan bakar minyak tanah, dapat diketahui bahwa semakin besar stelan (bukaan katup bahan bakar), menyebabkan boilling time semakin kecil (cepat) dan kebutuhan bahan bakar yang semakin besar. Waktu yang dibutuhkan untuk mendidihkan 1 liter air (boiling time) yang paling kecil (cepat) adalah pada stelan ke 4 yaitu 178,67 detik, sedangkan boiling time yang paling besar (lama) adalah pada stelan 1 yaitu 645,33 detik. Sedangkan bila dibandingkan dengan tungku desain baru yang menggunakan briket, boiling time kedua bahan bakar alternative (briket) tersebut masih lebih besar dibandingkan dengan tungku spiral stelan ke 4. yaitu masing-masing 390.67 detik untuk briket biomassa dan 255.33 detik untuk briket batubara. Sedangkan dilihat dari boiling time tungku spiral stelan ke 2 yang memiliki nilai 437.33, maka kedua bahan bakar alternative yang menggunakan tungku 
desain baru, memiliki boiling time yang lebih kecil (cepat).

\section{f. Perhitungan Lamanya waktu pengoperasian dalam 1 kali pengisian briket biomassa \\ Penelitian ini juga dilakukan untuk} melihat berapa waktu operasional tungku yang dapat dilakukan dalam 1 kali pengisian briket, dengan melihat korelasi kesepadanan tungku spiral minyak tanah dengan tungku baru berbahan bakar briket biomassa. Hal ini diperlukan untuk mengetahui apakah pemakaian briket ini dapat memberikan nilai tambah dari segi kemudahan pemakaian dan kontinyuitas operasional dibanding dengan bahan bakar lain seperti bongkahan batu bara atau kayu bakar, yang rata-rata memerlukan waktu 2 jam setiap pengisiannya.

Adapun perhitungannya adalah sebagai berikut:

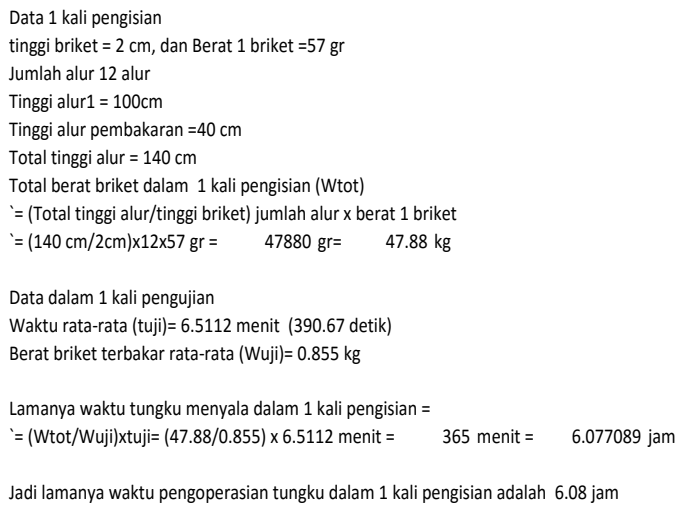

Dari penelitian dan perhitungan yang dilakukan maka, dengan tungku desain baru ini, dapat meningkatkan lamanya operasional dalam satu kali pengisian sampai 3 kali lipat yaitu dari 2 jam operasional menjadi 6 jam operasional dalam satu kali pengisian.

\section{Kesimpulan}

Berdasarkan analisis dan pembahasan yan telah dilakukan pada bab sebelumnya, maka dapat ditarik kesimpulan sebagai berikut:

a. Dari ketiga bahan bakar yang diuji, nilai kalor tertinggi adalah minyak tanah dengan nilai kalor, 9.828,2816 Kkal/kl, dan yang terendah adalah briket biomassa yang merupakan campuran 20 $\%$ biji jarak dan $80 \%$ arang sekam padi, dengan nilai kalor 4.996,5028 Kkal/kg.

b. Pada tungku spiral omprongan tembakau berbahan bakar minyak tanah, diperoleh kecedrungan bahwa semakin besar stelan (bukaan katup bahan bakar), menyebabkan boilling time semakin kecil (cepat) dan kebutuhan bahan bakar yang semakin besar. Waktu yang dibutuhkan untuk mendidihkan 1 liter air ( boiling time) yang paling kesil (cepat) adalah pada stelan ke 4 yaitu 178,67 detik, pada posisi ini, kebutuhan bahan bakarnya terbesar yaitu 103,33 $\mathrm{ml}$. Sedangkan boiling time yang paling besar (lama) adalah pada stelan 1 yaitu 645,33 detik, dan memerlukan bahan bakar yang paling sedikit yaitu 46,67 ml.

c. Dari pengujian tungku spiral dan tungku briket desain baru yang menggunakan dua bahan bakar alternative, boilling time kedua bahan bakar alternative (briket) tersebut masih lebih besar dibandingkan dengan tungku spiral stelan ke 4. yaitu masing-masing 390.67 detik untuk briket biomassa dan 255.33 detik untuk briket batubara. Sedangkan dilihat dari boiling time tungku spiral stelan ke 2 yang memiliki nilai 437.33, maka kedua bahan bakar alternative yang menggunakan tungku desain baru, memiliki boiling time yang lebih kecil (cepat)

d. Dari pengujian lama operasional tungku

berbahan bakar briket biomassa, dibandingkan dengan bongkahan batubara dan kayu bakar, diperoleh peningkatan lama operasional sebanyak tiga kali lipat. Bongkahan batubara dan kayu bakar, dalam satu kali pengisian dapat beroperasi selama maksimal 2 jam, sedangkan tungku desain baru berbahan bakar biomassa, dapat beroperasi 6 jam dalam satu kali pengisian.

e. Mekanisme kerja penekan briket, alur briket dan penahan ruang pembakaran dapat berjalan sesuai fungsinya sehingga, kontinyuitas tungku dalam 1 kali pengisian dapat berjalan dan beroperasi dengan stabil selama 6 jam.

\section{Daftar Pustaka}

Ang Ye Li, 1994, Desain Tungku untuk Industri Kecil, Seminar sehari dalam rangka memperingati 10 tahun Fakultas Teknik Universitas Mataram

Anon., 2004. Penyempurnaan Rencana Tata Ruang Wilayah Propinsi Nusa Tenggara Barat 2004, BAPPEDA Prop. NTB.

Direktorat Jenderal Bina Produksi Perkebunan Departemen Pertanian Jakarta, 2002. Laporan Kegiatan 
Monitoring dan Supervisi

Pelaksanaan Pengembangan

Agribisnis tembakau, Proyek

Pengembangan Kawasan Industri

Masyarakat Perkebunan (KIMBUN)

Pusat Tahun Anggaran 2002

Eddy H.T, 1990, Teknik Pembakaran Dasar dan Bahan Bakar, UTS Surabaya

Frank K. Arko P, 1986, Prinsip-Prinsip Perpindahan Panas, Erlangga Jakarta

Hummaidi, M , 2006,Pemanfaatan sekam padi menjadi bahan dasar pembuatan briket bioarang sebagai bahan bakar alternatif pengganti bahan bakar minyak (BBM), Skripsi Teknik Mesin Unram

http://mekanisasi.litbang.deptan.go.id, 2007), Rekayasa Oven Tembakau Virginia Menjadi Krosok Virginia FC (Flue Cured)

Kristanti, R, 2006, Pengujian Besar Energi Briket dari sampah organik, Skripsi Teknik Mesin, Unram

Seftifira L.KH , 2007, Analisa nilai kalor limbah kotoran kuda sebagai bahan bakar alternatif yang ramah lingkungan dengan berbasis sistem firolisis, Skripsi Teknik Mesin Unram

Sularso, 1991, Dasar-dasar Perencanaan dan Pemilihan Elemen Mesin, Pradnya Paramita Jakarta.

Tirtosastro, S. Hastono, A.D., Darmono, 2003, Perekayasaan Instalasi Pemanfaatan Udara Panas

\section{Buang pada Pengovenan Tembakau Virginia, Jurnal penelitian tanaman pangan vol.9}

Wijana, M, 2009, Pengaruh jenis bahan bakar dan tekanan udara terhadap karakteristik tungku gasifikasi tipe downdraft' Jurnal Penelitian Rekayasa: Vol 10

Wijana, M.,2010, Desain tungku briket arang biomassa system kontinyu berpengapian semi otomatis sebagai upaya mempermudah pemanfaatan energi alternatif mengganti minyak tanah. Procedding Seminar Nasional Teknik Mesin.

Wijana, M., 2010, Application Of Value Engineering To The Design Of Biomass Charcoal Briquet Stove With Continue System And Semi Automatic Ignitation As An Effort To Facilitate The Using Of Alternative Energy To Subtitute Petroleum "Procedding seminar internasional (ISECE)

Rachmanto, T., Wijana, M. Nurchayati, 2009., Pemanfaatan Tungku Energi Gasifikasi Sekam Padi Sebagai Energi Alternatif Pengganti Kompor Minyak Tanah dan Tungku Kayu Bakar Menuju Masyarakat Mandiri Energi di Daerah Tertinggal Rawan Kemiskinan, Laporan Program IbM. www.google. Jaringan Kerja Tungku Indonesia www.lomboktimur.go.id ,2008, Tembakau Virginia dan Kelestarian Lingkungan www.kapanlagi.com, 2008, NTB Kembangkan Produksi Tembakau Virginia 